Article

\title{
Restoration of Shallow Lakes in Subtropical and Tropical China: Response of Nutrients and Water Clarity to Biomanipulation by Fish Removal and Submerged Plant Transplantation
}

\author{
Jinlei Yu ${ }^{1, *}$, Zhengwen Liu ${ }^{1,2,3, *}$, Kuanyi Li ${ }^{1}$, Feizhou Chen ${ }^{1}$, Baohua Guan ${ }^{1}$, Yaohui Hu ${ }^{1}$, \\ Ping Zhong ${ }^{2}$, Yali Tang ${ }^{2}$, Xuefeng Zhao ${ }^{4}, \mathrm{Hu} \mathrm{He}^{1}{ }^{1}$, Haiyi Zeng ${ }^{2}$ and Erik Jeppesen ${ }^{3,5}$ \\ 1 State Key Laboratory of Lake Science and Environment, Nanjing Institute of Geography and Limnology, \\ Chinese Academy of Sciences, Nanjing 210008, China; kyli@niglas.ac.cn (K.L.); Feizhch@niglas.ac.cn (F.C.); \\ bhguan@niglas.ac.cn (B.G.); yhhu@niglas.ac.cn (Y.H.); hehu@niglas.ac.cn (H.H.) \\ 2 Department of Ecology and Institute of Hydrobiology, Jinan University, Guangzhou 510630, China; \\ tzping@jnu.edu.cn (P.Z.); litangyali@163.com (Y.T.); zenghaiyi2000@sina.com (H.Z.) \\ 3 Sino-Danish Centre for Education and Research (SDC), University of Chinese Academy of Sciences, \\ Beijing 100190, China; ej@bios.au.dk \\ 4 Beisun Environmental Technology Company, Guangzhou 510623, China; zxf1110@126.com \\ 5 Department of Bioscience, Aarhus University, 8600 Silkeborg, Denmark \\ * $\quad$ Correspondence: jlyu@niglas.ac.cn (J.Y.); zliu@niglas.ac.cn (Z.L.); Tel.: +86-25-8688-2213 (J.Y.); \\ +86-25-8688-2103 (Z.L.)
}

Academic Editor: Miklas Scholz

Received: 16 August 2016; Accepted: 29 September 2016; Published: 5 October 2016

\begin{abstract}
Fish removal has been used to restore temperate lakes, and positive effects on ecological state and water clarity have frequently been recorded in many lakes. Recently, a supplementary measure, transplantation of submerged macrophytes after fish removal, has been applied to restore warm Chinese shallow lakes in order to compensate for the expected lack of increasing grazing control of phytoplankton after the biomanipulation. These measures have successfully shifted turbid warm lakes to a clear water state, but little is known about the responses to restoration of key physico-chemical variables. We analyzed the seasonal variation in nutrient concentrations in two subtropical and one tropical biomanipulated shallow Chinese lakes subjected to restoration. In all three lakes, a marked decline occurred in the concentrations of lake total nitrogen (TN), total phosphorus (TP), total suspended solids (TSS), and chlorophyll $a(\mathrm{Chl} a)$, while the transparency (SD:WD ratio, Secchi depth to water depth ratio) increased. A clear water state was established, lasting so far for 7 to 23 months, and TN, TP, Chl $a$, and TSS levels in the three restored lakes decreased to, on average, $49 \%, 58 \%, 41 \%$, and $18 \%$ of the level prior to restoration and/or the level in a reference lake, respectively, while the annual mean SD:WD ratio exhibited a 1.5-4 fold increase. In conclusion, lake restoration by transplantation of submerged macrophytes after fish removal had major positive effects on the physico-chemical variables in our study lakes. However, continuous control of omnivorous and herbivorous fish biomass is recommended as the fish typically present in warm, shallow lakes to some extent feed on submerged macrophytes, when available.
\end{abstract}

Keywords: biomanipulation; subtropical; tropical; Chinese shallow lakes; nutrients; TSS; transparency

\section{Introduction}

In many countries world-wide, food web biomanipulation, such as removal of planktivorous and benthivorous-omnivorous fish and transplantation of submerged macrophytes, has been considered as an important and useful approach to restore eutrophic shallow lakes. Predation by planktivorous 
fish on zooplankton affects the abundance, size, and species composition of the zooplankton community [1,2] and thereby indirectly also the phytoplankton and physico-chemical conditions [3]. Benthivorous fish may induce resuspension of sediment, resulting in reduced water transparency, and increase the nutrient exchange between sediment and water [4-6]. Consequently, removal of planktivorous and benthivorous fish may produce strong cascading effects on phytoplankton, nutrients, as well as on water clarity $[7,8]$, and the method has been used to restore temperate lakes for many years $[3,4,8,9]$. In shallow lakes, water transparency may increase dramatically after fish community biomanipulation, and this may facilitate the reestablishment of submerged macrophytes [10]. Submerged macrophytes affect the physico-chemical environment and biota in shallow lakes $[11,12]$ and play a key role in maintaining a clear water state $[13,14]$ through a number of different mechanisms such as reduced resuspension of bottom sediments [15] and suppression of algal growth through competition with phytoplankton for nutrients [16,17]. Also, release of allelopathic substances by submerged macrophytes has been found to have negative impacts on algae growth $[18,19]$. Moreover, submerged macrophytes provide a refuge for zooplankton, which thus avoid predation by planktivorous fish [20], leading to a higher grazing pressure on phytoplankton [21]. Moreover, submerged macrophytes oxidize the sediment and increase its capacity of binding inorganic $\mathrm{P}$, thereby reducing $\mathrm{P}$ release to the water column [11].

One of the goals of restoring eutrophicated lakes in the temperate zone is to enhance grazer control of phytoplankton by herbivorous zooplankton. This may in part be achieved by establishing submerged macrophytes as they benefit visually foraging piscivorous fish, such as pike (Esox lucius) and perch (Perca fluviatilis), by providing habitats [22] and improved light conditions [23,24]. This, in turn, reduces the abundance of plankti-benthivorous fish through predation and competition, creating higher proportions of large-bodied zooplankton, a higher zooplankton:phytoplankton biomass ratio and an increased grazing pressure on phytoplankton, which ensures higher water transparency and further facilitates the growth of submerged macrophytes [25]. Thus, in temperate shallow lakes, top-down effects and macrophyte growth reinforce each other, which helps maintain the stability of a clear water state $[13,26]$. Therefore, to speed up the recovery after nutrient loading reduction, selective removal of zooplanktivorous fish has been conducted in many lakes in the temperate zone [2,7].

In warmer lakes, however, re-establishment of submerged macrophytes may have a comparatively weak effect on fish abundance and zooplankton biomass. Fish species richness is higher in warmer shallow lakes $[27,28]$, and the relative contribution of omnivores is typically higher in (sub)tropical than in temperate regions [28-30]. This also appears to be true when macrophytes are dominant or become dominant after restoration of subtropical [31] and tropical shallow lakes [32]. Moreover, the refuge effect for zooplankton is weak in warm lakes due to aggregation of fish predators in the vegetation $[33,34]$ and, in general, the fish predation pressure on zooplankton is high in the warm lakes $[35,36]$. The higher predation pressure on zooplankton in warm lakes may in part be due to dominance of omnivorous fish [30], as also seen in two restored Chinese shallow lakes, tropical Huizhou West Lake [37] and subtropical Lake Wuli [38]. While zooplankton is of great importance for young omnivorous fish, the adult fish consume macrophytes when abundant. In this way, omnivorous fish may maintain a high biomass [38] and, with that, high recruitment, which may in part explain the low abundance of cladocerans and the weak grazing on phytoplankton observed even in the restored sites [36], which contradicts the typical response of temperate lakes. Thus, bottom-up effects from submerged macrophytes were considered to be the main mechanisms for maintaining a clear water state in the tropical Huizhou West Lake [36].

While high predation on zooplankton seems unavoidable in warm lakes, submerged macrophytes may, for many reasons, still have strong effects on water clarity, as stated above. Fish manipulation is therefore often accompanied by transplanting a variety of macrophyte species into the lakes in order to stabilize the effect of fish removal and to stimulate macrophyte growth [36]. In the present study, we analyze how the seasonal variation in nutrient concentrations, chlorophyll $a$ in the water, and water 
transparency in three (sub)tropical Chinese lakes responded to biomanipulation (fish removal and reestablishment of submerged macrophytes).

\section{Materials and Methods}

\subsection{Description of the Study Lakes}

Lake Wuli $\left(31^{\circ} 32^{\prime} 05.82^{\prime \prime} \mathrm{N}, 120^{\circ} 14^{\prime} 12.16^{\prime \prime}\right.$ E) is a subtropical, shallow, hypereutrophic, and isolated bay in Lake Taihu, situated in Wuxi City in Jiangsu Province, China (Figure 1). It has a mean depth of $2.1 \mathrm{~m}$, a maximum depth of $3.4 \mathrm{~m}$, and a surface area of $860 \mathrm{ha}$. In the $1950 \mathrm{~s}, 98 \%$ of the lake area was covered by submerged macrophytes, and the water was clear [39,40], but from the 1960s, because of fish farming and increased external and internal nutrient loading, the submerged macrophytes disappeared and the lake became turbid and eutrophic [41]. With the aim of improving the water quality, a sub-basin of Lake Wuli, completely isolated from the main lake by dams built under two bridges, was selected to test the effect of ecological restoration. This sub-basin had a mean depth of about $2.0 \mathrm{~m}$ and a surface area of 5 ha. After water level reduction (pumping water to the main lake), coarse fish (mainly from the Cyprinidae family, $431 \mathrm{~kg} \cdot \mathrm{ha}^{-1}$ ) were removed in $2010 \mathrm{using}$ gillnets and electric fishing, the key target fish species being common carp Cyprinus carpio Linnaeus, crucian carp Carassius carassius Linnaeus, silver carp Hypophthalmichthys molitrix Valenciennes and bighead carp Hypophthalmichthys nobilis J. Richardson, and piscivorous fish (mandarin fish Siniperca chuatsi Basilewsky and snakehead fish Channa argus Cantor) were stocked (51 kg.ha- ${ }^{-1}$ at one time). In addition, submerged macrophytes were manually planted (about 30 adult plants per square meters), consisting of eel grass Vallisneria spinulosa Yan, hydrilla Hydrilla verticillata Royle, Eurasian watermilfoil Myriophyllum spicatum L., pondweeds Potamogeton maackianus Benn and Potamogeton malaianus Miq., and coontail Ceratophyllum demersum L.. Submerged macrophytes became the dominant primary producer after biomanipulation, with M. spicatum, P. malaianus, and P. maackianus as the key species, and the average biomass of submerged macrophytes was $1.7 \mathrm{~kg} \cdot \mathrm{WW} \cdot \mathrm{m}^{-2}$ (from August 2010 to November 2011, Guan et al., unpublished data).

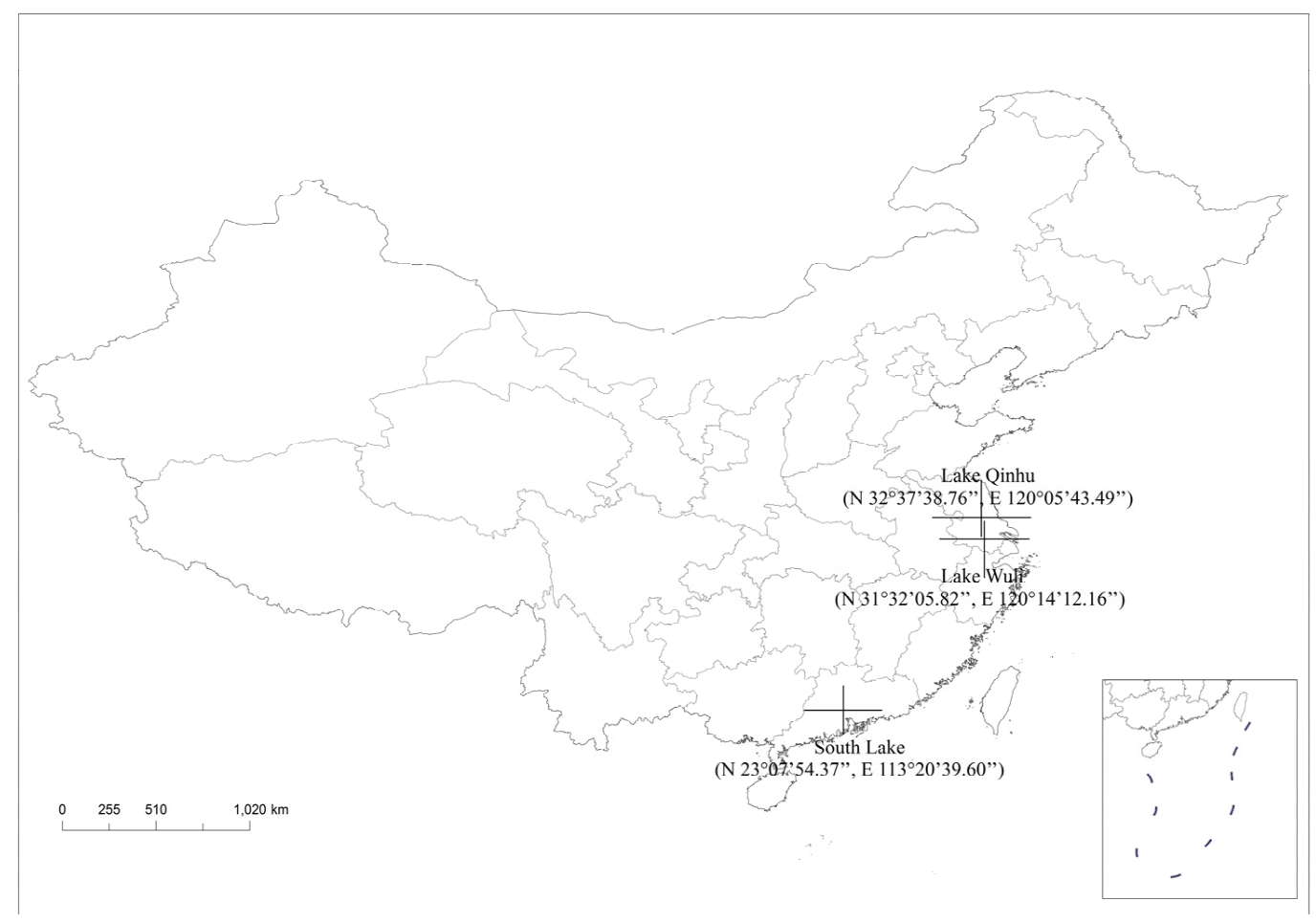

Figure 1. Map of China with the position of the three studied lakes. 
Lake Qinhu ( $\left.32^{\circ} 37^{\prime} 38.76^{\prime \prime} \mathrm{N}, 120^{\circ} 05^{\prime} 43.49^{\prime \prime} \mathrm{E}\right)$ is a subtropical shallow turbid lake situated by Taizhou City in Jiangsu Province, China (Figure 1). With the aim of improving the lake's water quality, a part was selected as an ecological restoration demonstration area that was completely isolated from the main lake by dams. This area was cut off from Lake Qinhu by two bridges. This basin had a mean depth of $1.5 \mathrm{~m}$ and a surface area of 8 ha and was restored by biomanipulation in the form of fish removal by drying the basin partially (a bridge crossing over the restored parts was built for tourism). We unfortunately lack information about the total biomass removed, but the key target fish species were C. carpio, C. carassius, H. molitrix and H. nobilis, followed by manually planting about 30 adult plants per square meters of $V$. spinulosa, $H$. verticillata, $M$. spicatum, and C. demersum in 2011. After restoration, the water became clear and the submerged macrophytes had a mean biomass of $1.6 \mathrm{~kg} \cdot \mathrm{WW} \cdot \mathrm{m}^{-2}$ (from September 2011 to March 2012, Guan et al., unpublished data).

South Lake $\left(23^{\circ} 07^{\prime} 54.37^{\prime \prime}\right.$ N, $113^{\circ} 20^{\prime} 39.60^{\prime \prime}$ E) at Jinan University, Guangzhou, Guangdong Province, China, is a tropical eutrophic shallow lake (Figure 1). It has a mean depth of $1.0 \mathrm{~m}$ and a surface area of 0.4 ha. The lake was restored by external loading reduction in 2013 through blocking of sewage inlet pipes [42], followed by fish removal with gillnets and electric fishing (mainly from the Cyprinidae family, $375 \mathrm{~kg} \cdot \mathrm{ha}^{-1}$ ), the key target species being Nile tilapia Oreochromis niloticus Linnaeus, C. carpio and C. carassius, and reestablishment of submerged macrophytes by manually planting about 70 adult plants individuals per square meter (V. spinulosa, H. verticillata, and M. spicatum) after lowering the water level in January-February 2014. After restoration, in September 2014, the coverage of submerged macrophytes reached $85 \%$ of the lake surface [42].

\subsection{Monitoring of Physical and Chemical Parameters}

The physical and chemical parameters of the lakes were monitored at three different sites in the restored and unrestored parts of Lake Wuli and Lake Qinhu, respectively. In South Lake at Jinan University, samples were taken from the same (three) sites before and after the ecological restoration. Concentrations of total nitrogen (TN), total phosphorus (TP), chlorophyll $a(\mathrm{Chl} a)$, and total suspended solids (TSS) of the water column, Secchi depth (SD) and water depth (D) were measured at least once a month at different sampling sites. For Lake Wuli, measurements were conducted from April of 2010 to February of 2012, and the summer measurement frequency was weekly in 2010 and monthly in 2011. For Lake Qinhu, data on physico-chemical parameters were collected monthly from May 2011 to March 2012. Before the restoration of South Lake at Jinan University, monitoring was conducted three times a month from October to December 2013 and twice a month from March to July as well as three times in August and once in September 2014 after finishing the restoration in January-February 2014.

A Secchi disc was used to measure SD, and water depth was recorded with a sensor (SM-5, Speedtech Instruments, USA) in each sampling site. The water samples, which were pooled from three sub-samples collected at different depths $(0.5,1.0$ and $1.5 \mathrm{~m})$, were collected with a $5 \mathrm{~L}$ water sampler at each sampling site, and a $5 \mathrm{~L}$ subsample was taken from each site and brought back to the laboratory. TN was determined using an alkaline potassium persulfate digestion-UV spectrophotometric method, and TP was determined following the ammonium molybdate spectrophotometric method after digestion with $\mathrm{K}_{2} \mathrm{~S}_{2} \mathrm{O}_{8}$ solution according to Chinese Standard Methods for Monitoring Lake Eutrophication [43]. Chl $a$ was measured using $90 \%(\mathrm{v} / \mathrm{v})$ acetone/water solution extraction followed by spectrophotometry and calculated without correcting for phaeophytin interference [44]. TSS samples were prepared by filtering 1-2 L lake water through pre-weighed GF/C filters, which were then dried at $60{ }^{\circ} \mathrm{C}$.

\subsection{Statistical Analyses}

Time course data, including chemical and physical data, and Chl $a$ concentrations for both the restored and unrestored parts of Lake Wuli and Lake Qinhu were compared between the treatments using an analysis of variances for repeated measures (rANOVA) applying a general linear model. Statistical tests could not be conducted for South Lake due to lack of a reference 
part. All data were appropriately transformed wherever necessary to meet the requirements of normal distribution and homogeneity of variances. All comparisons were performed with the statistical package SPSS version 22.0 (IBM Corporation, Somers, NY, USA).

\section{Results}

Overall, the average concentrations of TN, TP, Chl $a$, and TSS were lower in the restored parts of Lake Wuli and Lake Qinhu than in the unrestored areas (Table 1), and lower concentrations were also found in South Lake at Jinan University after restoration (Table 1). The SD:WD ratio was higher in the restored parts of Lake Wuli and Lake Qinhu than in the unrestored areas, and similarly the SD:WD ratio for South Lake increased after restoration (Table 1).

Table 1. Annual mean concentrations ( $\pm \mathrm{SE}$ ) of total nitrogen $(\mathrm{TN})$, total phosphorus (TP), chlorophyll (Chl $a$ ), total suspended solids (TSS), and water clarity (SD:WD ratio) in the restored and unrestored areas of Lake Wuli and Lake Qinhu, and in the pre-restoration and post-restoration phase of South Lake; and rANOVA statistical results of Lake Wuli and Lake Qinhu.

\begin{tabular}{|c|c|c|c|c|c|c|c|c|c|c|}
\hline \multirow[b]{2}{*}{ Parameters } & \multicolumn{4}{|c|}{ Lake Wuli } & \multicolumn{4}{|c|}{ Lake Qinhu } & \multicolumn{2}{|c|}{ South Lake* } \\
\hline & Unrestored & Restored & $\begin{array}{c}\mathrm{F} \\
\text { value }\end{array}$ & $\begin{array}{c}P \\
\text { value }\end{array}$ & Unrestored & Restored & $\begin{array}{c}F \\
\text { value }\end{array}$ & $\begin{array}{c}P \\
\text { value }\end{array}$ & Pre-restoration & Post-restoration \\
\hline $\mathrm{TN}\left(\mathrm{mg} \mathrm{L}^{-1}\right)$ & $1.2 \pm 0.3$ & $0.7 \pm 0.2$ & 155.5 & $<0.0001$ & $1.3 \pm 0.2$ & $0.8 \pm 0.2$ & 143.8 & $<0.0001$ & $3.3 \pm 0.9$ & $0.9 \pm 0.5$ \\
\hline $\mathrm{Chl} a\left(\mu \mathrm{g} \mathrm{L}^{-1}\right)$ & $15.6 \pm 8.9$ & $6.6 \pm 3.7$ & 545.0 & $<0.0001$ & $17.0 \pm 8.4$ & $9.1 \pm 4.8$ & 23.3 & 0.009 & $71.4 \pm 24.7$ & $19.0 \pm 9.2$ \\
\hline $\operatorname{TSS}\left(\mathrm{mg} \mathrm{L}^{-1}\right)$ & $20.3 \pm 8.0$ & $6.4 \pm 5.2$ & 89.1 & 0.001 & $34.1 \pm 14.5$ & $5.2 \pm 2.1$ & 746.7 & $<0.0001$ & $57.6 \pm 25.9$ & $3.3 \pm 2.3$ \\
\hline SD:WD ratio & $0.2 \pm 0.1$ & $0.8 \pm 0.2$ & 184.1 & $<0.0001$ & $0.2 \pm 0.1$ & $0.7 \pm 0.2$ & 192.5 & $<0.0001$ & $0.6 \pm 0.2$ & $0.9 \pm 0.1$ \\
\hline
\end{tabular}

\subsection{Response of TN and TP to Biomanipulation}

In Lake Wuli, TN in the restored area exhibited lower concentrations than in the unrestored area, especially during summer, and the levels were relatively stable in the restored area with only small fluctuations among the 43 samplings conducted from April 2010 to February 2012. Thus, annual mean $\mathrm{TN}$ concentrations dropped to $58 \%$ relative to the level in the unrestored area (Table 1). The frequency of occurrence of mean TN concentration $<1.0 \mathrm{mg} \cdot \mathrm{L}^{-1}$ was $95 \%$ for the restored and $30 \%$ for the unrestored area (Figure 2a). In contrast, the mean TP concentrations in restored Lake Wuli showed relatively large fluctuations compared to TN but were still lower than in the unrestored area (Table 1), especially during August-September 2010 (Figure 2b). The annual mean TP concentration was $69 \%$ of the level in the unrestored area (Table 1). The frequency of occurrence of a mean TP concentration $<50 \mu \mathrm{g} \cdot \mathrm{L}^{-1}$ was $81 \%$ for the restored and $49 \%$ for the unrestored area during the whole sampling campaign (Figure $2 b$ ).

In Lake Qinhu, the concentrations of TN in the restored part showed a similar pattern as that in Lake Wuli, with low level fluctuations throughout the whole monitoring period (Figure 3a). The mean TN concentration in the restored area of the lake was lower than in the unrestored area. The annual mean TN concentration was $62 \%$ of the level in the unrestored area (Table 1 ). The frequency of occurrence of mean TN concentrations $<1.0 \mathrm{mg} \cdot \mathrm{L}^{-1}$ in the restored area of Lake Qinhu was $73 \%$, which was much higher than the $9 \%$ recorded in the unrestored area during the whole monitoring period (Figure 3a). In contrast, the mean TP concentration in the restored area of Lake Qinhu showed relatively low fluctuations compared with the unrestored area (Figure $3 b$ ), and no significant differences occurred between the two parts of Lake Qinhu (Table 1). The annual mean concentration of TP in the restored part was $75 \%$ of the level in the unrestored area. The frequency of occurrence of mean TP concentration lower than $<50 \mu \mathrm{g} \cdot \mathrm{L}^{-1}$ was $55 \%$ for the restored and $27 \%$ for the unrestored area throughout the whole sampling campaign (Figure $3 b$ ). 

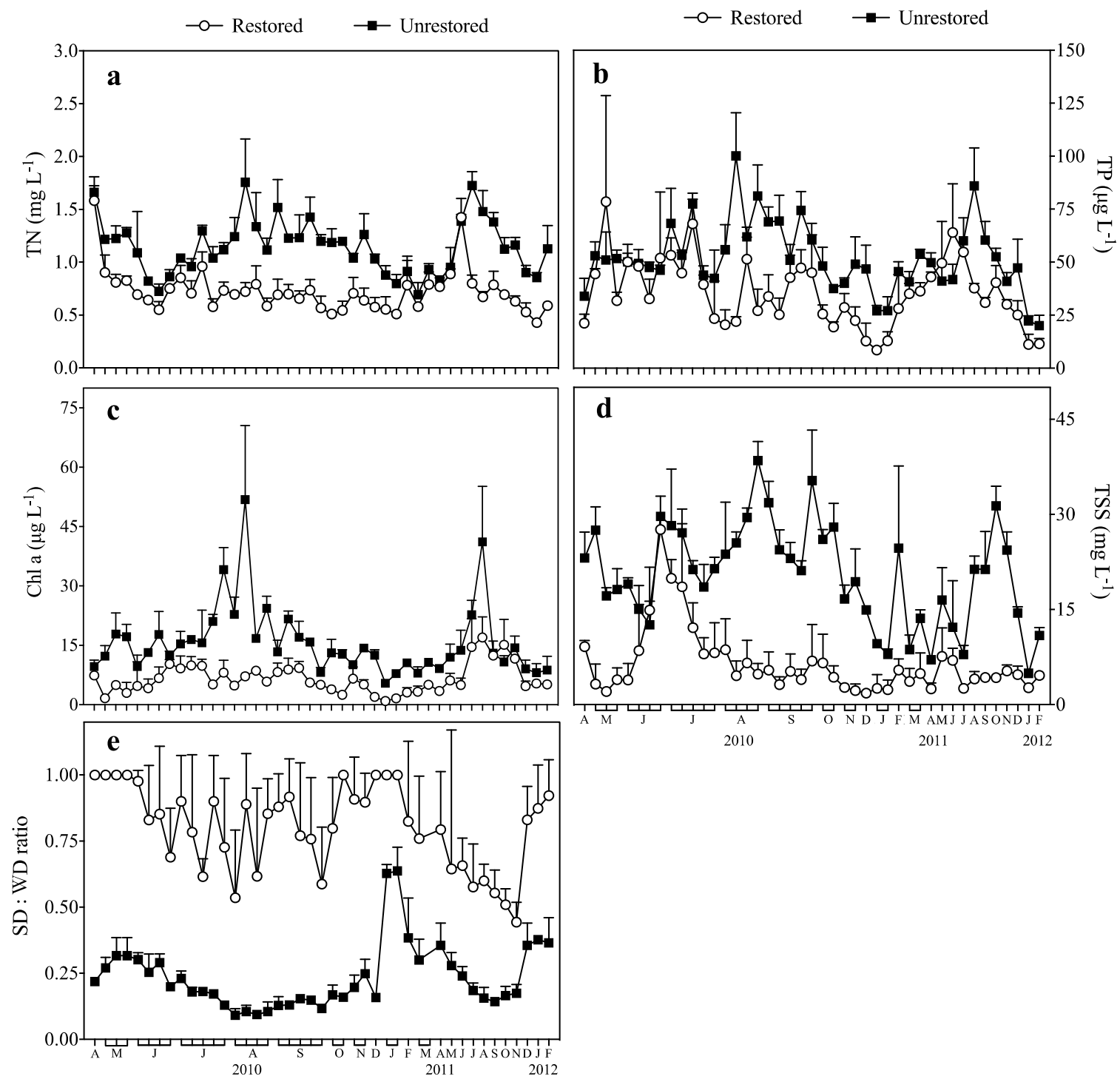

Figure 2. Seasonal changes in (a) total nitrogen (TN), (b) total phosphorus (TP), (c) chlorophyll $(\mathrm{Chl} a),(\mathbf{d})$ total suspended solids (TSS), and (e) water clarity (SD:WD ratio) levels in the restored and unrestored areas of Lake Wuli. Error bars represent the SD of different monitoring sites.

After the biological restoration of tropical shallow South Lake at Jinan University in January-February 2014, the concentrations of TN declined rapidly in April, followed by only low-level fluctuations (Figure 4a); the mean TN concentration of the lake after restoration was only $26 \%$ of the pre-restoration concentration (Table 1), and the occurrence frequency of a mean TN concentration lower than $1.0 \mathrm{mg} \cdot \mathrm{L}^{-1}$ being $86 \%$ for the whole monitoring period. A marked decrease was also found in mean TP concentrations in South Lake after restoration, which was $31 \%$ of the pre-restoration level (Table 1). The frequency of mean TP concentrations $<50 \mu \mathrm{g} \cdot \mathrm{L}^{-1}$ was $36 \%$ (Figure $4 \mathrm{~b}$ ), which is lower than in the subtropical restored area of Lake Wuli. 

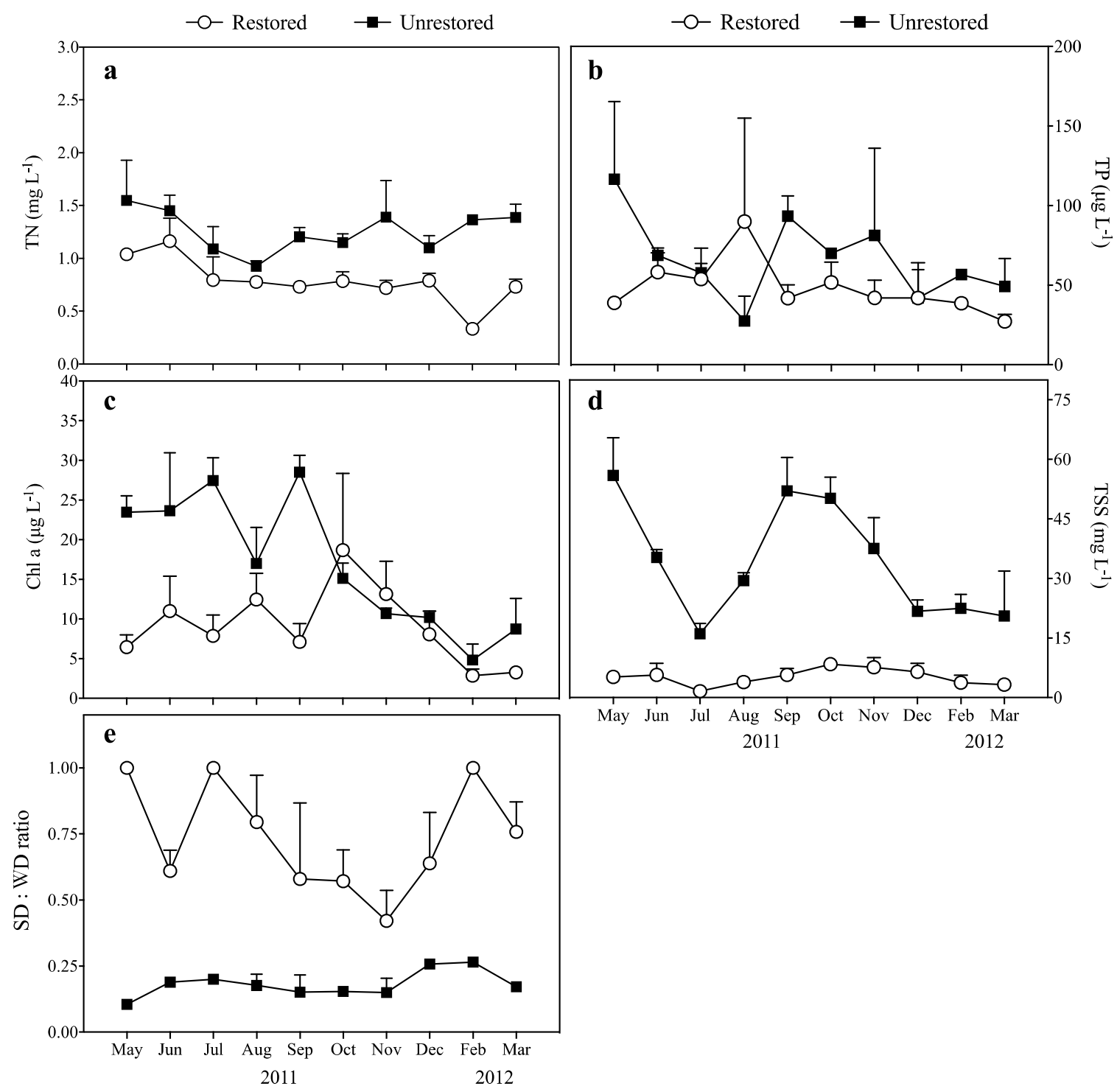

Figure 3. Seasonal changes in (a) total nitrogen (TN), (b) total phosphorus (TP), (c) chlorophyll $(\mathrm{Chl} a),(\mathbf{d})$ total suspended solids (TSS), and (e) water clarity (SD:WD ratio) levels in the restored and unrestored areas of Lake Qinhu. Error bars represent the SD of different monitoring sites.

\subsection{Response of Chl a to Biomanipulation}

The response of Chl $a$ to the biomanipulation measures implemented in Lake Wuli was pronounced; thus, mean summer Chl $a$ concentrations in the restored area were low, while higher $\mathrm{Chl} a$ levels were found in the unrestored part (Figure 2c). The annual mean Chl $a$ concentration in the restored part was $42 \%$ of the mean concentration in the unrestored area (Table 1 ). Moreover, the fluctuations in $\mathrm{Chl} a$ concentrations in the restored part of Lake Wuli were low compared with those observed in the unrestored part (Figure 2c). The frequency of mean Chl $a$ concentrations $<15 \mu \mathrm{g} \cdot \mathrm{L}^{-1}$ was $98 \%$ for the restored and $61 \%$ for the unrestored area during the whole sampling period (Figure 2c).

In Lake Qinhu, a notable seasonal change in Chl $a$ concentrations was recorded in the unrestored part with high summer levels and an annual mean concentration of $17 \mu \mathrm{g} \cdot \mathrm{L}^{-1}$. In contrast, summer $\mathrm{Chl} a$ concentrations were lower in the restored than in the unrestored area (Figure 3c), the annual mean concentration was $54 \%$ of the annual mean concentration in the unrestored part (Table 1). During 
the whole sampling period, an average $\mathrm{Chl} a<15 \mu \mathrm{g} \cdot \mathrm{L}^{-1}$ occurred in $90 \%$ of the sampling months in the restored part but only in $40 \%$ of the sampling months in the unrestored part (in winter).
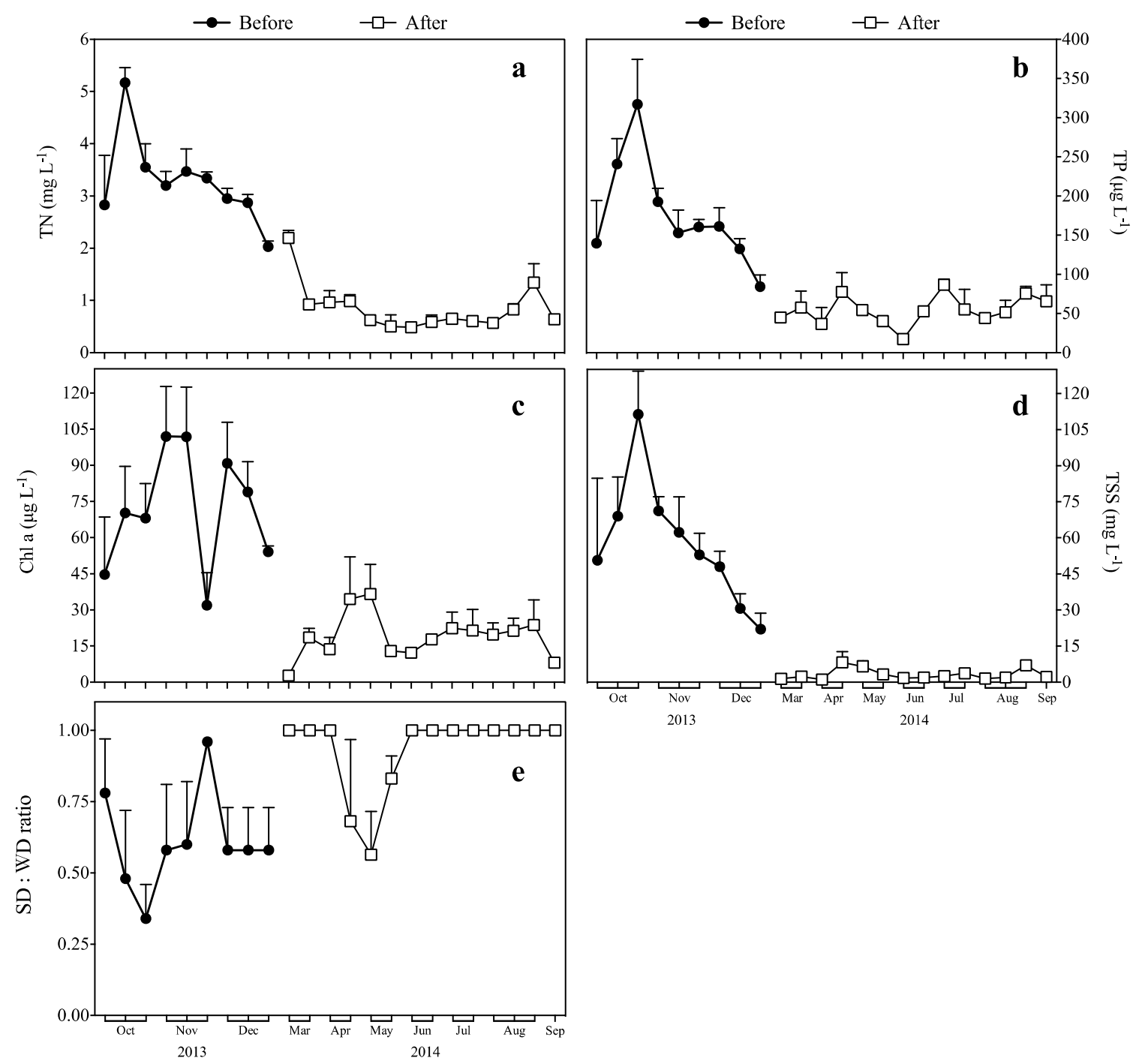

Figure 4. Seasonal changes in (a) total nitrogen (TN), (b) total phosphorus (TP), (c) chlorophyll $(\mathrm{Chl} a),(\mathbf{d})$ total suspended solids (TSS), and (e) water clarity (SD:WD ratio) levels before and after the restoration of South Lake at Jinan University. Error bars represent the SD of different monitoring sites.

The mean Chl $a$ concentrations of South Lake showed large fluctuations before restoration. After restoration, a notable decrease in Chl $a$ occurred in March 2014, after which levels were relatively stable and low until the end of the monitoring. The $\mathrm{Chl} a$ mean concentration decreased to only $27 \%$ of the pre-restoration level (Figure 4c). Only $36 \%$ of the sampling months after restoration exhibited Chl a concentrations $<15 \mu \mathrm{g} \cdot \mathrm{L}^{-1}$, a proportion much lower than in the other two subtropical restored lakes (Lake Wuli and Lake Qinhu).

\subsection{Response of TSS to Biomanipulation}

In Lake Wuli, mean TSS concentrations in the unrestored part fluctuated widely during the whole monitoring period (Figure 2d), and only in $28 \%$ of the sampling months did TSS values $<15 \mathrm{mg} \cdot \mathrm{L}^{-1}$ occur. TSS in the restored area of Lake Wuli also showed large variations from August 2010 to the end of the monitoring period, but the values were lower than in the unrestored area, especially in summer (Figure 2d), and the annual mean concentration of TSS was 32\% of the level in the unrestored area 
(Table 1). Overall, the percentage of months having a TSS level $<15 \mathrm{mg} \cdot \mathrm{L}^{-1}$ in the restored part of Lake Wuli was as high as $93.0 \%$ and thus much higher than in the unrestored area $(28 \%)$.

Similar patterns to those recorded in the unrestored part of Lake Wuli emerged for mean TSS concentrations in the unrestored area of Lake Qinhu; here, large fluctuations occurred during the whole monitoring period, i.e., $>15 \mathrm{mg} \cdot \mathrm{L}^{-1}$ in all months (Figure $3 \mathrm{~d}$ ). The mean TSS concentration in the restored area of the lake was lower than in the unrestored area (Table 1). The proportion of months with TSS $<15 \mathrm{mg} \cdot \mathrm{L}^{-1}$ was $100 \%$ in the restored area where TSS showed little fluctuation during the sampling months. In the restored area, TSS averaged $5 \mathrm{mg} \cdot \mathrm{L}^{-1}$, which was equal to only $15 \%$ of mean TSS in the unrestored area (Figure 3d).

In South Lake, extremely high TSS concentrations were found in late October 2013 before restoration, after which a gradual decline was observed until the end of December (Figure 4d) following the external nutrient loading reduction. However, after the in-lake biological restoration, which was finished in January-February 2013, very low concentrations of TSS were recorded throughout the rest of the monitoring period, with only small fluctuations (the annual mean concentration was only $6 \%$ of the mean concentration before restoration) (Figure $4 \mathrm{~d}$ ).

\subsection{Response of the SD:WD Ratio to Biomanipulation}

In all the study lakes, the SD:WD ratio responded quickly to the biomanipulation, always being higher in the restored than in the unrestored area of Lake Wuli where the annual mean SD:WD ratio of the restored area was 4 times higher than in the unrestored area (Table 1) (Figure 2e). The proportion of months with a ratio $>0.5$ was $98 \%$ in the restored area and only $4.7 \%$ in the unrestored area of Lake Wuli (Figure 2e). Similar patterns were revealed in Lake Qinhu where the SD:WD ratio showed relatively wide fluctuations in the restored area but only small changes in the unrestored area (Figure 2e). However, for $89 \%$ of the sampling events, a SD:WD ratio $>0.5$ (light to the bottom) was recorded, whereas the SD:WD ratio for the unrestored area never exceeded 0.5 (Figure 3e). The SD:WD ratio in the restored area was 3.5 times higher than in the unrestored part.

In South Lake, the SD:WD ratio increased rapidly to 1.0 in March after restoration, indicating light to the bottom. Afterwards, the average ratio declined to 0.6 in May 2014 but returned to 1.0 in early June (Figure 4e). After restoration, mean SD:WD ratios $>0.5$ were recorded in all months, and the annual mean ratio was $153 \%$ of the level before restoration (Table 1).

\section{Discussion}

The biomanipulation (fish removal combined with submerged macrophyte transplantation) of the three eutrophic shallow lakes in subtropical and tropical areas of China was successful as judged from the declining concentrations of TN, TP, Chl $a$, and TSS and the increased water transparency (SD:WD ratio) after restoration (Figures 1-3). The concentrations of TN, TP, Chl $a$, and TSS in the tropical South Lake decreased by 69\%-94\% compared with the levels before restoration. Similarly, mean concentrations of TN, TP, Chl $a$, and TSS were $31 \%-68 \%$ and $25 \%-85 \%$ lower in the restored sections of subtropical and shallow Lake Wuli and Lake Qinhu, respectively, compared with the unrestored sections. Mean concentrations of TN and TSS were $<1.0 \mathrm{mg} \cdot \mathrm{L}^{-1}$ and $<10.0 \mathrm{mg} \cdot \mathrm{L}^{-1}$, respectively, in the restored sections of Lake Wuli and Lake Qinhu, as well as in South Lake after restoration. The mean concentration of $\mathrm{Chl} a$ was $<10 \mu \mathrm{g} \cdot \mathrm{L}^{-1}$ in the restored areas of Lake Wuli and Lake Qinhu, and the mean concentration of Chl $a$ in South Lake after restoration was about $20 \mu \mathrm{g} \cdot \mathrm{L}^{-1}$. There is no reference basin for South Lake and external nutrient loading was reduced 3 months before the biomanipulation. Although the response of this lake to biomanipulation is similar to that observed in the other two lakes, the results from South Lake should be interpreted with caution as some improvements were seen already in the first 3 months after nutrient loading reduction, i.e., before biological intervention.

In temperate lakes, fish removal has also resulted in major reductions in $\mathrm{TN}$ and $\mathrm{TP}[8,34,45]$. In a study of 36 Danish lakes (mainly shallow and eutrophic), concentrations of TN, TP, Chl $a$, 
and TSS decreased by 30\%-50\% relative to the level prior to fish removal [8], which is lower than the decline observed in our study lakes. This most likely reflects the more comprehensive restoration conducted in our study, which combines the more traditional fish removal with submerged macrophyte transplantation. This dual treatment was undertaken for several reasons: First, strong grazer control by zooplankton after fish removal is unlikely to occur due to the dominance of small and quickly reproducing fish [46]. In accordance with this, several studies have shown a fast return of fish and a shift back to the turbid state in (sub)tropical lakes. For instance, in subtropical Lake Naini Tal, India, after a fish kill comprising $>80 \%$ of the most abundant fish species, the planktivorous mosquito fish Gambusia affinis, nutrient concentrations decreased and water clarity increased [47], but three months later the water conditions had almost returned to their former state. In a lake in Uruguay, similar observations were made after a fish kill [48]. By contrast, a relatively low Chl $a$ concentration and high water clarity were recorded in a tropical Brazilian reservoir (Lake Paranoá) for $>10$ years after fish manipulation, but in this case it is difficult to disentangle the specific effects of the two measures applied (flushing and biomanipulation) [3]. Second, submerged macrophytes may have a particular stabilizing effect in warm lakes compared with temperate lakes; in the former they can maintain high biomasses throughout winter, thereby preventing spring blooming [49].

The clear water state with abundant submerged macrophytes has so far lasted for 7 months in tropical South Lake and for 10 and 23 months in subtropical Lake Qinhu and Lake Wuli, respectively. In the restored part of tropical Huizhou West Lake, the dominance of submerged macrophytes and a clear water state have now lasted for $>7$ years [3,36]. This provides further evidence [3] of the usefulness of biomanipulation as a restoration technique in warm shallow eutrophic lakes after a sufficiently high external loading reduction. However, in temperate lakes, repeated fish removal is suggested to obtain a longer-lasting clear water state $[3,50]$, and such repeated removal may also be recommended for warm shallow lakes. The warm lakes are dominated by omnivorous fish in both the turbid and the clear water states [32], and it has been shown that adult omnivores feed mainly on submerged macrophytes in the restored part of Huizhou West Lake [37] as well as in Lake Wuli [38], and high abundances of these species could lead to a return of the turbid state.

Acknowledgments: The authors thank Sipeng Yao, Ke Li, Deyong Zhou, Xubo Liu, Ming Zhang, Yachan Ji, Yuhui Kang, Wei Zhen, Deyuan Chen, Rili He, Jiayong Mo, and Xiaoyan Zhang for field and laboratory support and Anne Mette Poulsen for language assistance. Thanks also go to Pingping Liu from Nanjing Zhongke Water Environment Engineering Co. Ltd, who provided the initial biomass data on the removed fish. This study was supported by the National Basic Research Program of China (No. 2012CB956100) and the National Natural Science Foundation of China $(31270409,31370477,31400400)$. EJ was further supported by the MARS project (Managing Aquatic ecosystems and water Resources under multiple Stress) funded under the 7th EU Framework Programme, Theme 6 (Environment including Climate Change), Contract No. 603378 (http://www.mars-project.eu), and CLEAR (a Villum Kann Rasmussen Centre of Excellence project).

Author Contributions: ZL, KL, and FC designed the study, YH, PZ, JY, HZ, BG, YT, and XZ conducted the sampling, JY, ZL, HH, and EJ conducted the data analyses and wrote the paper.

Conflicts of Interest: The authors declare no conflict of interest.

\section{References}

1. Brooks, J.L.; Dodson, S.I. Predation, body size, and composition of plankton. Science 1965, 150, $28-35$. [CrossRef] [PubMed]

2. Jeppesen, E.; Jensen, J.P.; Søndergaard, M.; Lauridsen, T.; Landkildehus, F. Trophic structure, species richness and biodiversity in Danish lakes: Changes along a phosphorus gradient. Freshw. Biol. 2000, 45, 201-213. [CrossRef]

3. Jeppesen, E.; Søndergaard, M.; Lauridsen, T.; Davidson, T.A.; Liu, Z.; Mazzeo, N.; Trochine, C.; Özkan, K.; Jensen, H.S.; Trolle, D.; et al. Biomanipulation as a restoration tool to combat eutrophication: Recent advances and future challenges. Adv. Ecol. Res. 2012, 47, 411-488. 
4. Meijer, M.L.; Jeppesen, E.; Van Donk, E.; Moss, B.; Scheffer, M.; Lammens, E.; Van Nes, E.; Van Berkum, J.A.; de Jong, G.J.; Faafeng, B.A.; et al. Long-term responses to fish-stock reduction in small shallow lakes: Interpretation of five year results of four biomanipulation cases in the Netherlands and Denmark. Hydrobiologia 1994, 275, 457-466. [CrossRef]

5. Scheffer, M.; Portielje, R.; Zambrano, L. Fish facilitate wave resuspension of sediment. Limnol. Oceanogr. 2003, 48, 1920-1926. [CrossRef]

6. Volta, P.; Jeppesen, E.; Leoni, B.; Campi, B.; Sala, P.; Garibaldi, L.; Lauridsen, T.; Winfield, I.J. Recent invasion by a non-native cyprinid (common bream Abramis brama) is followed by major changes in the ecological quality of a shallow lake in southern Europe. Biol. Invasions 2013, 15, 2065-2079. [CrossRef]

7. Hansson, L.A.; Annadotter, H.; Bergman, E.; Hamrin, S.F.; Jeppesen, E.; Kairesalo, T.; Luokkanen, E.; Nilsson, P.A.; Søndergaard, M.; Strand, J. Biomanipulation as an application of food-chain theory: Constraints, synthesis, and recommendations for temperate lakes. Ecosystems 1998, 1, 558-574. [CrossRef]

8. Søndergaard, M.; Liboriussen, L.; Pedersen, A.R.; Jeppesen, E. Lake restoration by fish removal: Short- and long-term effects in 36 Danish lakes. Ecosystems 2008, 11, 1291-1305. [CrossRef]

9. Shapiro, J.; Wright, D.I. Lake restoration by biomanipulation: Round Lake, Minnesota, the first two years. Freshw. Biol. 1984, 14, 371-383.

10. Meijer, M.L.; De Boois, I.; Scheffer, M.; Portielje, R.; Hosper, H. Biomanipulation in shallow lakes in the Netherlands and Denmark. Hydrobiologia 1999, 409, 13-30. [CrossRef]

11. Carpenter, S.R.; Lodge, D.M. Effects of submerged macrophytes on ecosystem processes. Aquat. Bot. 1986, 26, 341-370. [CrossRef]

12. Jeppesen, E.; Lauridsen, T.L.; Kairesalo, T.; Perrow, M.R. Impact of submerged macrophytes on fish-zooplankton interactions in lakes. In The Structuring Role of Submerged Macrophytes in Lakes, 1st ed.; Jeppesen, E., Søndergaard, M., Søndergaard, M., Christoffersen, K., Eds.; Ecological Studies Series; Springer: New York, NY, USA, 1998; pp. 91-114.

13. Moss, B. Engineering and biological approaches to the restoration from eutrophication of shallow lakes in which aquatic plant communities are important components. Hydrobiologia 1990, 200, 367-377. [CrossRef]

14. Scheffer, M.; Jeppesen, E. Alternative stable states. In The Structuring Role of Submerged Macrophytes in Lakes, 1st ed.; Jeppesen, E., Søndergaard, M., Søndergaard, M., Christoffersen, K., Eds.; Ecological Studies Series; Springer: New York, NY, USA, 1998; pp. 397-406.

15. Horppila, J.; Nurminen, L. Effects of submerged macrophytes on sediment resuspension and internal phosphorus loading in Lake Hiidenvesi (southern Finland). Water Res. 2003, 37, 4468-4474. [CrossRef]

16. Van Donk, E.; Gulati, R.D.; Iedema, A.; Meulemans, J.T. Macrophyte-related shifts in the nitrogen and phosphorus contents of the different trophic levels in a biomanipulated shallow lake. Hydrobiologia 1993, 251, 19-26. [CrossRef]

17. Kosten, S.; Kamarainen, A.; Jeppesen, E.; van Nes, E.H.; Peeters, E.T.H.M.; Mazzeo, N.; Hauxwell, J.; Hansel-Welch, N.; Lauridsen, T.L.; Søndergaard, M.; et al. Likelihood of abundant submerged vegetation growth in shallow lakes differs across climate zones. Glob. Chang. Biol. 2009, 15, 2503-2517. [CrossRef]

18. Gross, E.M. Allelopathy of aquatic autotrophs. Crit. Rev. Plant Sci. 2003, 22, 313-339. [CrossRef]

19. Vanderstukken, M.; Mazzeo, N.; Van Colen, W.; Declerck, S.; Muylaert, K. Biological control of phytoplankton by the subtropical submerged macrophytes Egeria densa and Potamogeton illinoensis: A mesocosm study. Freshw. Biol. 2011, 56, 1837-1849. [CrossRef]

20. Lauridsen, T.L.; Pedersen, L.J.; Jeppesen, E.; Søndergaard, M. The importance of macrophyte bed size for cladoceran composition and horizontal migration in a shallow lake. J. Plankton Res. 1996, 18, 2283-2294. [CrossRef]

21. Jeppesen, E.; Søndergaard, M.; Søndergaard, M.; Christoffersen, K.; Theil-Nielsen, J.; Jürgens, K. Cascading trophic interactions in the littoral zone: an enclosure experiment in shallow Lake Stigsholm, Denmark. Arch. Hydrobiol. 2002, 153, 533-555.

22. Casselman, J.M.; Lewis, C.A. Habitat requirements of northern pike (Esox lucius). Can. J. Fish Aquat. Sci. 1996, 53, 161-174. [CrossRef]

23. Lehtiniemi, M.; Engström-Öst, J.; Viitasalo, M. Turbidity decreases anti-predator behavior in pike larvae, Esox lucius. Environ. Biol. Fish 2005, 73, 1-8. [CrossRef]

24. Salonen, M.; Engström-Öst, J. Prey capture of pike Esox Lucius larvae in turbid water. J. Fish Biol. 2010, 76, 2591-2596. [CrossRef] [PubMed] 
25. Lauridsen, T.L.; Jeppesen, E.; Søndergaard, M. Colonization and succession of submerged macrophytes in shallow Lake Væng during the first five years following fish manipulation. Hydrobiologia 1994, 275, 233-242. [CrossRef]

26. Scheffer, M.; Hosper, S.; Meijer, M.; Moss, B.; Jeppesen, E. Alternative equilibria in shallow lakes. Trends Ecol. Evol. 1993, 8, 275-279. [CrossRef]

27. Zhao, S.; Fang, J.; Peng, C.; Tang, Z.; Piao, S. Patterns of fish species richness in China's lakes. Glob. Ecol. Biogeogr. 2006, 15, 386-394. [CrossRef]

28. Teixeira-de Mello, F.; Meerhoff, M.; Pekcan-Hekim, Z.; Jeppesen, E. Substantial differences in littoral fish community structure and dynamics in subtropical and temperate shallow lakes. Freshw. Biol. 2009, 54, 1202-1215. [CrossRef]

29. Moss, B. Climate change, nutrient pollution and the bargain of Dr Faustus. Freshw. Biol. 2010, 55, $175-187$. [CrossRef]

30. González-Bergonzoni, I.; Meerhoff, M.; Davidson, T.A.; Teixeira-de Mello, F.; Baattrup-Pedersen, A.; Jeppesen, E. Meta-analysis shows a consistent and strong latitude pattern in fish omnivory across ecosystems. Ecosystems 2012, 15, 492-503.

31. Chen, K.; Bao, C.; Zhou, W. Ecological restoration in eutrophic Lake Wuli: A large enclosure experiment. Ecol. Eng. 2009, 35, 1646-1655. [CrossRef]

32. Gao, J.; Liu, Z.; Jeppesen, E. Fish community assemblages changed but biomass remained similar after lake restoration by biomanipulation in a Chinese tropical eutrophic lake. Hydrobiologia 2014, 724, 127-140. [CrossRef]

33. Meerhoff, M.; Mazzeo, N.; Moss, B.; Rodríguez-Gallego, L. The structuring role of free-floating versus submerged plants in a subtropical shallow lake. Aquat. Ecol. 2003, 37, 377-391. [CrossRef]

34. Jeppesen, E.; Meerhoff, M.; Jakobsen, B.A.; Hansen, R.S.; Søndergaard, M.; Jensen, J.P.; Lauridsen, T.L.; Mazzeo, N.; Branco, C. Restoration of shallow lakes by nutrient control and biomanipulation-The successful strategy depends on lake size and climate. Hydrobiologia 2007, 581, 269-288. [CrossRef]

35. Meerhoff, M.; Clemente, J.M.; Teixeira-de Mello, F.; Iglesias, C.; Pedersen, A.R.; Jeppesen, E. Can warm climate-related structure of littoral predator assemblies weaken the clear water state in shallow lakes? Glob. Chang. Biol. 2007, 13, 1888-1897. [CrossRef]

36. Liu, Z.W.; Zhong, P.; Zhang, X.; Ning, J.; Larsen, S.E.; Jeppesen, E. Successful restoration of a tropical shallow eutrophic lake: Strong bottom-up but weak top-down effects recorded. Australia-China wetland network research partnership. In Proceedings of the Australia-China Wetland Network Research Partnership Symposium, Nanjing, China, 23-28 March 2014; Kattel, G., Ed.; Federation University Australia: Mt. Helen, Australia, 2014; pp. 78-86.

37. Rao, W.; Ning, J.; Zhong, P.; Jeppesen, E.; Liu, Z. Size-dependent feeding of omnivorous Nile tilapia in a macrophyte-dominated lake: Implications for lake management. Hydrobiologia 2015, 749, 125-134. [CrossRef]

38. Yu, J.; Liu, Z.; He, H.; Zhen, W.; Guan, B.; Chen, F.; Li, K.; Zhong, P.; Teixeira-de Mello, F.; Jeppesen, E. Submerged macrophytes facilitate dominance of omnivorous fish in a subtropical shallow lake: Implications for lake restoration. Hydrobiologia 2016, 775, 97-107. [CrossRef]

39. Zhu, S.P. Variety of water quality in whole year in the northern of Taihu Lake. Oceanol. Limnol. Sin. 1959, 2, 146-162. (In Chinese)

40. Wu, X.W. Investigation of limnology in Lake Wuli in 1951. Acta Hydrobiol. Sin. 1962, 1, 63-113. (In Chinese)

41. Chen, F.; Shu, T.; Jeppesen, E.; Liu, Z.; Chen, Y. Restoration of a subtropical eutrophic shallow lake in China: effects on nutrient concentrations and biological communities. Hydrobiologia 2013, 718, 59-71. [CrossRef]

42. Zeng, H.; Zhong, P.; Zhao, X.; Li, C.; He, X.; Liu, Z. Response of metazoan zooplankton communities to ecological restoration in a tropical shallow lake. J. Lake Sci. 2016, 28, 170-177. (In Chinese)

43. Jin, X.; Tu, Q. The Standard Methods for Observation and Analysis in Lake Eutrophication, 2nd ed.; Chinese Environmental Science Press: Beijing, China, 1990. (In Chinese)

44. SEPA. Analytical Methods for Water and Wasterwater Monitor, 4th ed.; Chinese Environmental Science Press: Beijing, China, 2002. (In Chinese)

45. Ibelings, B.W.; Portielje, R.; Lammens, E.H.R.R.; Noordhuis, R.; Van den Berg, M.S.; Joosse, W.; Meijer, M.L. Resilience of alternative stable states during the recovery of shallow lakes from eutrophication: Lake Veluwe as a case study. Ecosystems 2007, 10, 4-16. [CrossRef] 
46. Meerhoff, M.; Teixeira-de Mello, F.; Kruk, C.; Alonso, C.; González-Bergonzoni, I.; Pacheco, J.P.; Lacerot, G.; Arim, M.; Beklioğlu, M.; Brucet, S.; et al. Environmental warming in shallow lakes: A review of potential changes in community structure as evidenced from space-for-time substitution approaches. Adv. Ecol. Res. 2012, 46, 259-349.

47. Nagdali, S.S.; Gupta, P.K. Impact of mass mortality of a mosquito fish, Gambusia affinis on the ecology of a fresh water eutrophic lake (Lake Naini Tal, India). Hydrobiologia 2002, 468, 45-52. [CrossRef]

48. Iglesias, C.; Mazzeo, N.; Meerhoff, M.; Lacerot, G.; Clemente, J.; Scasso, F.; Kruk, C.; Goyenola, G.; Garcia, J.; Amsinck, S.L.; et al. High predation is the key factor for dominance of small-bodied zooplankton in warm lakes-Evidence from lakes, fish exclosures and surface sediment. Hydrobiologia 2011, 667, 133-147. [CrossRef]

49. Liu, W.; Hu, W.; Chen, Y.; Gu, X.; Hu, Z.; Chen, Y.; Ji, L. Temporal and spatial variation of aquatic macrophytes in West Taihu Lake. Acta Ecol. Sin. 2007, 27, 159-170. (In Chinese)

50. Søndergaard, M.; Lauridsen, T.L.; Johansson, L.S.; Jeppesen, E. Repeated fish removal to restore lakes: case study Lake Væng, Denmark-two biomanipulations during 30 years of monitoring. Water 2016, in press.

(C) 2016 by the authors; licensee MDPI, Basel, Switzerland. This article is an open access article distributed under the terms and conditions of the Creative Commons Attribution (CC-BY) license (http://creativecommons.org/licenses/by/4.0/). 